\title{
Underestimation of chemical contamination in marine fish muscle tissue can be reduced by considering variable wet:dry weight ratios
}

\author{
Cresson Pierre ${ }^{1,{ }^{*}}$, Travers-Trolet Morgane ${ }^{1}$, Rouquette Manuel ${ }^{1}$, Timmerman Charles-Andre ${ }^{1}$, \\ Giraldo Carolina ${ }^{1}$, Lefebvre Sebastien ${ }^{1,2}$, Ernande Bruno ${ }^{1}$
}

${ }^{1}$ Ifremer, HMMN, Centre Manche - Mer du Nord, BP 669, F-62 321 Boulogne sur Mer, France

2 Univ. Lille, CNRS, Univ. Littoral Côte d'Opale, UMR 8187, LOG, Laboratoire d'Océanologie et de Géosciences, 28 avenue Foch, F-62 930 Wimereux, France

* Corresponding author : Pierre Cresson, email address : pierre.cresson@ifremer.fr

\begin{abstract}
:
Whether considered as a risk for human health or as ecological tracers, contaminants' concentrations measured in fish muscles are commonly expressed relative to wet or dry mass. Comparison of results required conversion factors (CF) but accurate values are scarce and case-specific. The present paper is aimed at investigating errors linked with the use of the theoretical value. Muscles dry and wet masses were measured in 15 fish species to determine the actual CF. Most CF were lower than the theoretical wet:dry ratio of 5 classically used, with variations at individual and species level. Muscle lipid content (inferred by $\mathrm{C} / \mathrm{N}$ ratios) was a crucial factor explaining discrepancies, claiming for caution when working with lipid-rich species. The observed variability demonstrated that using the theoretical CF may be inaccurate, when actual CF largely differs from the theoretical value. Dedicated measurement is the better approach when accuracy is required.
\end{abstract}




\section{Graphical abstract}

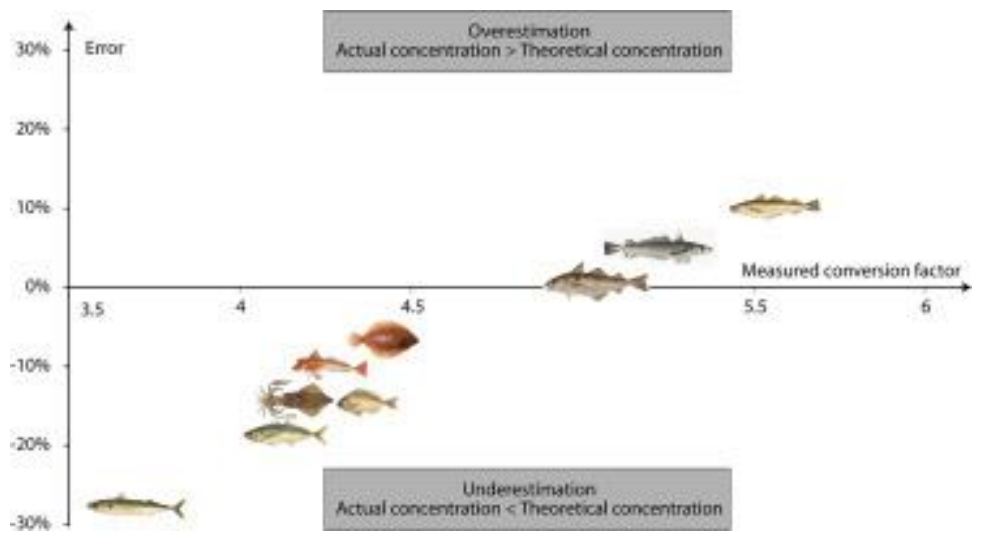

\section{Highlights}

- Conversion factor differs between fish species. Most values were different from 5, whereas this factor is largely used. Lipid was a major driver of discrepancies. Sanitary decision based on converted values may be dubious.

Keywords : Wet:dry ratio, Conversion factor, Contaminant concentration, Marine fish, Percentage of humidity 


\section{Introduction}

Chemical contamination in marine fish is a crucial question, since it alters individual metabolism and ecosystem functioning (Fleeger et al., 2003; Tartu et al., 2013) and affects human populations consuming fish (Eto, 2000; Endo et al., 2015). In a human-health focused approach, contaminant concentrations are measured in fresh fish tissues (mostly muscle, since this is the main consumed tissue) and are compared with threshold values defined by health agencies' regulatory guidelines relative to wet mass. Consumption of predatory fish is for example considered safe by several agencies worldwide if total mercury concentration in foodstuff is below $1 \mathrm{mg} \mathrm{g}^{-1}$ wet mass (EC, 2006; CCCF, 2013; McKinney et al., 2016). At the same time, the recent use of contaminants as tracers of ecological processes requires dried samples, since contaminant concentrations are measured jointly with other tracers such as $\mathrm{C}$ and $\mathrm{N}$ stable isotope ratios, the measurement of which is performed on dried material (Fisk et al., 2002; Cresson et al., 2015b; McKinney et al., 2016). Thus, the use of dry mass concentrations collected as ecological tracers for human-health purposes and their comparison with threshold values relative to wet mass would require weighing samples before and after drying, a time-consuming step omitted in most ecological studies. Dry mass concentrations are thus converted into wet mass concentrations using theoretical conversion factors, calculated based on the following formula:

$C w=C d \times\left(\frac{100-\% H}{100}\right)$

where $\mathrm{Cd}$ and $\mathrm{Cw}$ are the concentrations expressed relatively to dry and wet mass respectively, and with the percentage of humidity in wet tissues $(\% \mathrm{H})$ classically ranging around $80 \%$ for a vast range of species (Murray and Burt, 1969; Hislop et al., 1991; Payne et al., 1999; Environmental Protection Agency, 2011; Alonso-Fernández and Saborido-Rey, 2012). Consequently, authors assumed a conversion factor $C F=\frac{\mathrm{Cd}}{\mathrm{Cw}}=\frac{100}{100-\% \mathrm{H}}=\frac{\mathrm{mw}}{\mathrm{md}}$ of 5 between wet and dry mass $\frac{\mathrm{mw}}{\mathrm{md}}$ (and thus between dry and wet mass concentrations $\frac{\mathrm{Cd}}{\mathrm{Cw}}$ ) (Magalhães et al., 2007; Harmelin-Vivien et al., 2009; Cossa et al., 2012; Cresson et al., 2014a, 2015a; Bonito et al., 2016). The accuracy of this value and its general application whatever the species and their origin can be questioned, since spatial and specific variations were detected when the actual conversion factor was measured (Kojadinovic et al., 2006; Magalhães et al., 2007; Environmental Protection Agency, 2011; McKinney et al., 2016). Although these studies measured accurate conversion factors for their samples, they did not specifically investigate the factors driving these variations and their relative importance. Notably, variation in the lipid content of tissues is expected to be a major factor affecting the wet:dry mass ratio, as a strong 
negative relationship between lipid and moisture content was already observed (e. g. Hislop et al., 1991; Payne et al., 1999) but this possible effect has not been explicitly tested.

The aim of the present study was to document actual wet: dry ratios for 15 fish species sampled in the English Channel, with special focus on inter-specific, intra-specific, and intra-individual variability of this ratio. This work provides also an opportunity to question the use of generalized conversion factors and the potential associated errors.

\section{Materials and methods}

Individuals included in the present work were collected in the Western English Channel during the CAMANOC ("CAMpagne ecosystémique en MANche OCcidentale") survey operated on board of R/V Thalassa in September and October 2014. CAMANOC is a scientific survey designed to assess the functioning of the English Channel ecosystem by investigating all of its components, from hydrological parameters to high trophic level species (Travers-Trolet and Verin, 2014). Specifically, abundance of demersal fish species was investigated using a GOV bottom trawl towed during 30 minutes at a constant speed of 4 knots. Immediately after trawling, all fish were sorted, identified and measured to the lower nearest centimeter. 10 individuals per species were collected in the modal size-class at each of the 30 stations considered here (Fig. S1) when possible (i.e. for sufficiently abundant and/or frequent species) and frozen on-board at $-20^{\circ} \mathrm{C}$. The whole dataset comprised 848 individuals representing 15 fish species (Tab. 1).

In the laboratory, individuals were thawed and their total length was accurately measured to the nearest $\mathrm{mm}$. A muscle sample without skin ( $2 \mathrm{~g}$ wet mass) was sampled from the caudal peduncle, following the standard protocol for $\mathrm{Hg}$ analysis (Nakhlé et al., 2007; Cresson et al., 2015a). A sample of white dorsal muscle was also collected for isotopic analyses. Comparison of both muscle samples allowed investigating the intra-individual variability in wet:dry mass ratio. All muscle samples were precisely weighed $(0.001 \mathrm{mg})$ immediately after dissection (wet mass). Samples were frozen at $-80^{\circ} \mathrm{C}$ for $24 \mathrm{~h}$ and then freeze-dried for at least $24 \mathrm{~h}$. Dry mass was measured after freeze-drying, consistently with previous studies (Alonso-Fernández and Saborido-Rey, 2012). Freeze drying is better suited than other drying procedures as it removes water only, and volatile compounds, such as lipids, are not lost. Dorsal muscle samples were then grinded prior to the measurement of their $\mathrm{C} / \mathrm{N}$ ratio and their nitrogen isotopic ratio (referred to as $\delta^{15} \mathrm{~N}$ hereafter) measurements.

$\mathrm{C} / \mathrm{N}$ ratios are usually considered as a proxy of lipid content, the higher the $\mathrm{C} / \mathrm{N}$ ratio, the higher the lipid content (Post et al., 2007; Hoffman et al., 2015). Interestingly, C/N ratios are commonly measured jointly with $\mathrm{C}$ and $\mathrm{N}$ stable isotope ratios, as carbon isotopic ratios measured in samples 
with high $\mathrm{C} / \mathrm{N}$ ratios require correction for high lipid content. Thus, when contaminants and stable isotope ratios are measured jointly in the same muscle sample, $\mathrm{C} / \mathrm{N}$ ratios could provide a convenient proxy of lipid content if dedicated lipid measurement is not feasible or available. $\mathrm{C} / \mathrm{N}$ ratios were calculated based on the measurement of elemental C and N percentage with a Carlo Erba NC2500 elemental analyzer. Nitrogen stable isotopic ratios were measured with a Thermo Delta $V$ isotope mass ratio spectrometer. Accuracy of the $\delta^{15} \mathrm{~N}$ measurements was checked by repeated analyses of an in-house standard (one analysis of the standard after every 10 samples) with overall standard deviation of $0.07 \%$. Values were then used to calculate individual trophic levels $\left(\mathrm{TL}_{\text {fish }}\right)$ with the following formula:

$T L_{\text {fish }}=T L_{\text {baseline }}+\frac{\delta^{15} N_{f i s h}-\delta^{15} N_{\text {baseline }}}{T E F}$,

where $\delta^{15} \mathrm{~N}_{\text {fish }}$ and $\delta^{15} \mathrm{~N}_{\text {baseline }}$ are the nitrogen isotopic ratios of the individual fish and the trophic baseline respectively, and TEF is the trophic enrichment factor, set to $3.4 \%$ at each trophic level, following the most common approach for fish (e. g. Chouvelon et al., 2012; Cresson et al., 2014b). The queen scallop Aequipecten opercularis was chosen as the trophic baseline and attributed a trophic level ( $T L_{\text {baseline}}$ ) of 2 (Jennings and Warr, 2003; Trueman et al., 2016) and also considering the importance of benthic food sources in trophic web of this shallow environment, even for pelagic species (Kopp et al., 2015; Giraldo et al., 2017). Spatial variation of isotopic baseline was taken into account for the calculation of the trophic level of each fish by using the $\delta^{15} \mathrm{~N}$ value measured for scallops collected at the same station $\left(\delta^{15} \mathrm{~N}\right.$ values ranging between 4.24 and $8.58 \%$; S. Dubois, unpubl. data).

In addition to the 15 species listed in Table 1, some individuals of Solea solea, Lophius piscatorius and Loligo forbesii were also collected and processed following the same protocol previously described. But as this paper is focused on fish, and sample size was low for S. solea and L. piscatorius, isotopic ratios were not measured for these species that were not included in statistical analyses. Results for these species are consequently not discussed in the present paper but are provided for informative purposes in Table S1, as they have a commercial importance, and specific conversion factors may thus be of interest in contamination studies.

Error associated with the use of the theoretical conversion factor of 5 rather than the measured conversion factor CF was estimated with the following formulas.

$$
\begin{aligned}
& C w_{\text {actual }}=\frac{C d_{\text {measured }}}{C F} \text { and } C w_{\text {theoretical }}=\frac{C d_{\text {measured }}}{5} \\
& \text { Thus, Error }=C w_{\text {theoretical }}-C w_{\text {actual }}=\frac{C d_{\text {measured }}(C F-5)}{5 C F}
\end{aligned}
$$


With $\mathrm{Cd}$ the concentration expressed relatively to dry mass, $\mathrm{Cw}$ the concentration expressed relatively to wet mass, and CF the measured conversion factor. Actual and theoretical refers as to values measured or estimated respectively and error is the error in concentration value due to conversion. Finally, percentage of error was calculated as the ratio between error and the concentrations expressed relatively to wet mass, calculated using measured conversion factor:

$\% E_{d}=\frac{C d_{\text {measured }}}{5 C F}(C F-5) \times \frac{C F}{C d_{\text {measured }}}=\frac{C F-5}{5}$

Since data were not normally distributed, interspecific comparison in wet:dry ratio was assessed by Kruskal-Wallis non-parametric ANOVA, followed by post-hoc pairwise multiple comparison of mean ranks. Differences between measured ratio and the theoretical ratio of 5 were tested with nonparametric Wilcoxon tests. Differences in the relationship between species and biological co-variable (length, $\mathrm{C} / \mathrm{N}$ ratio and trophic level) were assessed with ANCOVAs, followed by Tukey posthoc comparisons. Homoscedasticity and normal distribution of residuals were reached before ANCOVAs with Box-Cox transformation $(\lambda=0.34)$ and checked with visual examination of residuals vs. fitted and $Q Q$ plots. Correlations between wet:dry ratio and $\mathrm{C} / \mathrm{N}$ ratio, trophic level and total length were assessed by non-parametric Spearman's rank correlation test. At individual level, difference in wet:dry ratio measured in dorsal and caudal muscle was assessed by Wilcoxon's ranked test, as observations are paired (Sokal and Rohlf, 1995). All analyses were run using R statistical software and car, MASS, multcomp, and PMCMR libraries (Hothorn et al., 2008; Fox and Weisberg, 2010; Venables and Ripley, 2013; R Core Team, 2015; Pohlert, 2015). Plots were produced with ggplot2 package (Wickham, 2009)

\section{Results and discussion}

The measured wet:dry mass ratio did not vary largely between species although variation was significant (Kruskall Wallis $\chi^{2}=631.35, p$-value $<0.0001$; Fig. 1). Extreme values were observed for Scomber scombrus (3.62 \pm 0.33$)$ and Merlangius merlangus $(5.51 \pm 0.44)$. Values measured for other species ranged between $4.18 \pm 0.34$ (Trachurus trachurus) and $5.25 \pm 0.14$ (Merluccius merluccius). The average measured value of the wet:dry mass ratio was significantly lower than the theoretical ratio of 5 for 10 species (Tab.2) . The measured ratio was not significantly different from 5 for 4 species (Microchirus variegatus, Melanogrammus aeglefinus, Trisopterus luscus and Merluccius merluccius) and it was significantly higher than 5 for M. merlangus only (Tab.2). In addition, $80 \%$ of all individual values measured across all species were lower than this threshold. These results seem consistent with published values measured in other environments. For example, Panichev and Panicheva (2015) measured the wet:dry mass ratio in several fish species and observed high interspecific variability, with higher values $(4.75 \pm 0.17)$ in Merluccius capensis, just as in the present 
study where M. merluccius is one of the species with the highest ratios. Comparisons with previous results can also be made using the percentage of humidity $\% \mathrm{H}$ as $C F=\frac{100}{100-\% \mathrm{H}}$. Also in this case, the species' average values measured in the present study largely fit with previous results in raw fish muscle (Environmental Protection Agency, 2011; Kojadinovic et al., 2006). Therefore, it seems that the standard theoretical conversion factor of 5 is inaccurate for most species. In addition, interspecific variability, notably highlighted by the large difference observed between the conversion factors of S. scombrus and M. merlangus, calls for an investigation of its driving factors at specific and individual levels.

The high wet:dry ratios recorded for $M$. merlangus might be related with the low lipid content of this species. Previous results demonstrated that whiting muscle represent a low nutritional input, due to low lipid and high water content (Hislop et al., 1991; Environmental Protection Agency, 2011). In the review made by the US Environmental Protection Agency (2011), whiting is one of the few species with \%H higher than $80 \%$. Interestingly, values higher than $80 \%$ were also reported for monkfish, consistently with the results obtained for L. piscatorius in the present study (Table S1). Käkelä et al (2007) notably observed that the lipid content in the muscle of a $22-\mathrm{cm}$ whiting is 10 times lower than that of a 13-cm sardine Sardina pilchardus. In lipid-poor species, water content in muscle is high and the loss of mass during freeze-drying is important, explaining the highest ratio observed for this species, and the only one to be significantly higher than 5. Contrarily, in lipid-rich species, like S. scombrus or T. trachurus, proportion of water in fresh muscle is lower. Since freeze-drying does not affect lipid content of a sample and removes water only, the loss of mass would be lower for a muscle sample with high lipid content, explaining the lower wet:dry ratio in lipid rich species. High lipid content in S. scombrus muscle was observed during dissection and freeze drying, confirmed by the high $\mathrm{C} / \mathrm{N}$ ratio measured (Tab. 1; Kopp et al. 2015). High lipid content was also measured for individuals collected in 2015 in the same zone ( $7 \%$ of total muscle mass, P. Cresson unpubl. data). Finally, previously published results are in accordance with high lipid content and low percentage of humidity for this species (Murray and Burt, 1969; Hardy and Keay, 1972; Environmental Protection Agency, 2011; Panichev and Panicheva, 2015). In addition, C/N and wet:dry ratios are strongly and negatively correlated for some species (Fig. 2), meaning that the higher the $\mathrm{C} / \mathrm{N}$ (and consequently the lipid content) the lower the wet:dry ratio. The strongest correlations were notably observed for S. scombrus, T. trachurus and S. cantharus, i.e. the three species with the highest $\mathrm{C} / \mathrm{N}$ ratios, confirming the importance of lipid as a factor driving the loss of mass during freeze-drying. Nevertheless, the wet:dry ratio calculated for $T$. trachurus is not significantly different from average values measured for other species, with lower $\mathrm{C} / \mathrm{N}$ ratios. This similarity may result from the absence of a direct straightforward link between $\mathrm{C} / \mathrm{N}$ and lipid content, notably evidenced by the various 
mathematical relationships designed to predict lipid content from C/N (Fagan et al., 2011; Hoffman et al., 2015; Sardenne et al., 2015). Consistently with those results, it is impossible to obtain accurate lipid content directly from the $\mathrm{C} / \mathrm{N}$ ratio value and additional studies measuring lipid content, $\mathrm{C} / \mathrm{N}$ and wet:dry ratios simultaneously on the same samples may be useful for a deeper understanding of the relationship between these parameters. Similarly, even if the conversion studied here mostly applies to metallic contamination, this further investigation may also be needed when working with lipophilic compounds, like PCBs, as lipid concentration is a direct driver of contamination (e.g Bodiguel et al., 2009). But rather than in a continuous approach, $\mathrm{C} / \mathrm{N}$ ratios can be interpreted following a discrete approach, separating species with high and low $\mathrm{C} / \mathrm{N}$ ratios. For example, $S$. scombrus having the outsider value for $\mathrm{C} / \mathrm{N}$ also displayed the lowest wet:dry ratio. It is also interesting to note that correlations between $\mathrm{C} / \mathrm{N}$ and wet:dry ratios are the highest for the three species with $\mathrm{C} / \mathrm{N}$ ratios higher than 3.5 (Tab. 3), the value commonly proposed as a threshold above which stable isotope ratios can be biased by high lipid content (Post et al., 2007). So, when isotopes and contaminants are measured on the same sample, high (>3.5) $\mathrm{C} / \mathrm{N}$ values can be seen as a double warning sign, precluding from the direct use of raw $\delta^{13} \mathrm{C}$ without correction for high lipid content, and also of the use of the theoretical dry to wet conversion factor of 5.

The present dataset, gathering several individuals of different sizes and trophic levels for most species, allowed examining how wet:dry ratios vary within species according to growth or associated dietary changes (Tab. 3). Significant effects of biological variables were detected, but differences were scarce and largely driven by species with extreme values, as denoted by the results of the posthoc tests (Tab. S2). Correlations between length and wet:dry ratio were low or non-significant for most species except S. scombrus and Zeus faber (Fig. S2). Similar pattern was observed for trophic level with rather low $(<0.3)$ or non-significant correlations for all species (Fig. S3). Nevertheless, the highest conversion factors were measured for L. piscatorius, M. merlangus and M. merluccius, i.e. piscivorous species commonly exhibiting some of the highest trophic levels in fish assemblages (Jennings and van der Molen, 2015). Even if a poor correlation between trophic level and conversion factor was detected at individual level, the pattern observed for these three species may be linked with the high protein content of the diet for piscivorous species and preferential routing of protein (but not lipids) through digestion. This preferential processing is commonly proposed as an explanation of the different nitrogen trophic enrichment factors (difference between diet and consumer isotopic ratio) measured between piscivores and herbivores (Mill et al., 2007).

This absence of effect of growth on lipid content for individuals at adult stage is consistent with previous analyses worldwide (Payne et al., 1999; Lloret and Planes, 2003) and seems to demonstrate that wet:dry ratio is fixed at species level, and may be constrained by metabolic processes when 
dietary input remains within tolerable limits. This pattern may also support the application of one specific conversion factor for all individuals of one species, provided that sample size is large enough to capture most interspecific variability. Further generalization of this assumption would nevertheless require measurement of ratios for these species at least in other environments.

A significant negative correlation between wet:dry ratio and length is observed for $S$. scombrus (Fig. S2), suggesting an influence of lipid dynamics and accumulation through growth in this species. The larger the fish, the higher the $\mathrm{C}: \mathrm{N}$ ratio and the lipid content. This effect may be linked with seasonal variation of lipid content. High lipid content in mackerel tissues were previously measured in October, as a result of an intense feeding activity in summer to prepare reproduction season (Wallace, 1991). The high values measured in the present study for fish collected at the same season are thus consistent with this observation. Unfortunately, sex of the individuals was not determined in the present study, but difference in lipid dynamics between males and females was previously observed and may also affect wet:dry ratio (Merayo, 1996). The important transfer of lipids from body to gonads during oogenesis significantly affects lipid content of females (Merayo, 1996; Bodiguel et al., 2009). Comparison of wet:dry ratio between males and females and at different periods of the sexual cycle may be useful to gain accuracy on the factors driving variations of the ratio.

Comparison of wet:dry ratio between dorsal and caudal muscle (i.e. at individual level) demonstrated homogeneity within individuals (Fig. 3). The significant correlation observed here for most species may support the hypothesis of a similar percentage of humidity in all muscle tissues within an individual and the use of a single factor to convert concentrations measured in several muscle tissues, as required by the amount of matter needed when several analyses are performed on the same individual (e. g. Cresson et al., 2015b). Correlations between ratios in both tissues were detected in all species except 5 . In A. imperialis, L. whiffiagonis and M. merluccius, the low sample size ( 8,7 and 6 individuals respectively) may have driven the absence of correlation, as it gives large weigh to some outlier values. Further analyses on larger datasets may be needed to reach a formal conclusion for these species. Regarding M. merlangus and T. Iuscus, general pattern of low lipid content of these species may originate the absence of correlation (Käkelä et al., 2007; Merayo, 1996). In these two species, wet:dry ratio is fairly constant in dorsal muscle but highly variable in caudal muscle (Fig. 3). Constant lipid content in fish dorsal muscle is an expected result, as it was the rationale for the use of this tissue in isotopic analyses (Pinnegar and Polunin, 1999). The variability in wet:dry ratio in caudal muscle could be linked with the storage of lipids in this tissue (Robinson and Mead, 1973). As lipid content is expected to be low in these species, a slight increase due to increased nutritional inputs may cause this large variability. 
Results of the present study demonstrated that actual conversion factors diverge in some extent from the theoretical value of 5 commonly used, under the influence of several factors, some of them investigated here (e.g. lipid content, inferred from $\mathrm{C} / \mathrm{N}$ ratio) and some other the effect of which still has to be determined accurately (e.g. sex). Determining the magnitude and the consequences of the associated error is the next step, and the dataset generated in this study was used to do so. The first point to be considered is the magnitude of the difference between actual and theoretical conversion factors. When actual conversion factor is largely lower than 5 (e.g for S. scombrus in the present study), error is ca $30 \%$ (Fig. 4). Implications of these differences may be profound for scientific interpretations or sanitary decisions based on converted values. The magnitude of the error demonstrates that this calculation should be avoided to infer decision on product consumption for lipid-rich species like S. scombrus. More generally, when measured conversion factors are lower than 5 , concentrations resulting from the use of the theoretical conversion factor are lower than actual values. Thus values resulting from conversion using the theoretical conversion factor should be used with most extreme caution, as most species displayed measured conversion factors lower than the theoretical value, in the present study (i.e. all species but the 6 displayed with black or grey symbols in Fig.4) and in other works (e. g. Murray and Burt, 1969; Hislop et al., 1991; Kojadinovic et al., 2006). Conversion factor measured for M. merluccius, M. merlangius and L. piscatorius also claimed for some caution but with lower risk. For these species, magnitude of the error is also linked with the difference between measured and theoretical conversion factors, but with inverted misestimation. As the values are higher than 5 , concentrations issued from conversion are higher than actual values. Sanitary decision based on this value would thus be somehow cautious, but with poor accuracy As most studies have been conducted to measure chemicals burdens in fish tissues, with human health or ecological purposes, several works use a theoretical conversion factors to compare concentrations expressed relatively to wet or dry mass, but without actual assessment of the accuracy of this value. Values measured here demonstrated large discrepancy driven by biological variables. The use of the theoretical value is doubtful and hazardous, notably for lipid-rich species, the actual wet:dry ratio of which is largely different from average values. As for $\delta^{13} \mathrm{C}$ analyses, $\mathrm{C} / \mathrm{N}$ ratios higher than 3.5 appeared as a threshold above which using theoretical conversion value may lead to major errors. The results of the present study demonstrated that using actual conversion factors, measured at least at specific level, is needed when accuracy is required or when sanitary decisions have to be taken based on these values. 


\section{Acknowledgments}

Financial support for this work was provided by Ifremer Scientific Direction, through the RETROGRAD "Politique de Site" grant and by the French government and the region Hauts-de-France in the framework of the project CPER 2014-2020 MARCO. We would like to thank the crew of R/V Thalassa for their help with sampling during CAMANOC survey, to the staff of the Cornell University Stable Isotope laboratory for fish isotopic and $\mathrm{C} / \mathrm{N}$ ratios measurements, Khalef Rhabi for technical support during fish dissections, and to Marc Bouchoucha (Ifremer/LER-PAC) and Sophie Fonfec for fruitful exchanges on conversion steps. Queen scallop isotopic ratios are courtesy of Stanislas F. Dubois (Ifremer/DYNECO) to whom we are also grateful.

\section{Bibliographical references}

Alonso-Fernández, A., Saborido-Rey, F., 2012. Relationship between energy allocation and reproductive strategy in Trisopterus luscus. Journal of Experimental Marine Biology and Ecology 416-417, 8-16. doi:10.1016/j.jembe.2012.02.001

Bodiguel, X., Loizeau, V., Le Guellec, A.-M., Roupsard, F., Philippon, X., Mellon-Duval, C., 2009. Influence of sex, maturity and reproduction on PCB and p, $p^{\prime} D D E$ concentrations and repartitions in the European hake (Merluccius merluccius, L.) from the Gulf of Lions (N.W. Mediterranean). Science of the Total Environment 408, 304-311. doi:10.1016/j.scitotenv.2009.10.004

Bonito, L.T., Hamdoun, A., Sandin, S.A., 2016. Evaluation of the global impacts of mitigation on persistent, bioaccumulative and toxic pollutants in marine fish. PeerJ 4, e1573.

CCCF, 2013. Discussion paper on the guideline levels for methylmercury in fish and predatory fish.

Chouvelon, T., Spitz, J., Cherel, Y., Caurant, F., Mendez-Fernandez, P., Autier, J., Lassus-Débat, A., Chappuis, A., Bustamante, P., 2012. Enhanced bioaccumulation of mercury in deep-sea fauna from the Bay of Biscay (North-East Atlantic) in relation to trophic position identified by analysis of carbon and nitrogen stable isotopes. Deep Sea Research I 113-124.

Cossa, D., Harmelin-Vivien, M., Mellon-Duval, C., Loizeau, V., Averty, B., Crochet, S., Chou, L., Cadiou, J.F., 2012. Influence of bioavailability, trophic position, and growth on methylmercury in hakes (Merluccius merluccius) from Northwestern Mediterranean and Northeast Atlantic. Environmental Science and Technology 46, 4885-4893.

Cresson, P., Bouchoucha, M., Miralles, F., Ellebode, R., Mahé, K., Maruszcak, N., Thebault, H., Cossa, D., 2015a. Are red mullets efficient as bio-indicators of mercury contamination? A case study from the French Mediterranean. Marine Pollution Bulletin 91, 191-199. doi:http://dx.doi.org/10.1016/j.marpolbul.2014.12.005

Cresson, P., Bouchoucha, M., Morat, F., Miralles, F., Chavanon, F., Loizeau, V., Cossa, D., 2015b. A multitracer approach to assess the spatial contamination pattern of hake (Merluccius merluccius) in the French Mediterranean. Science of The Total Environment 532, 184-194. doi:10.1016/j.scitotenv.2015.06.020

Cresson, P., Fabri, M.C., Bouchoucha, M., Brach-Papa, C., Chavanon, F., Jadaud, A., Knoery, J., Miralles, F., Cossa, D., 2014a. Hg in organisms from the Northwestern Mediterranean slope: importance of the food sources. Science of The Total Environment 497-498, 229-238. doi:10.1016/j.scitotenv.2014.07.069

Cresson, P., Ruitton, S., Ourgaud, M., Harmelin-Vivien, M., 2014b. Contrasting perception of fish trophic level from stomach content and stable isotope analyses: A Mediterranean artificial reef experience. Journal of Experimental Marine Biology and Ecology 452, 54-62. 
EC, 2006. Commission Regulation (EC) No 1881/2006 of 19 December 2006 setting maximum levels for certain contaminants in foodstuffs.

Endo, T., Hayasaka, M., Ogasawra, H., Kimura, O., Kotaki, Y., Haraguchi, K., 2015. Relationships among Mercury Concentration, and Stable Isotope Ratios of Carbon and Nitrogen in the Scalp Hair of Residents from Seven Countries: Effects of Marine Fish and $\mathrm{C}_{4}$ Plants Consumption. PLOS ONE 10, e0128149.

Environmental Protection Agency, 2011. Exposure factors handbook. 2011 edition. Office of Research and Development, United States Environmental Protection Agency., Washington, D.C.

Eto, K., 2000. Minamata disease. Neuropathology 20, 14-19.

Fagan, K.-A., Koops, M.A., Arts, M.T., Power, M., 2011. Assessing the utility of C: N ratios for predicting lipid content in fishes. Canadian Journal of Fisheries and Aquatic Sciences 68, 374385.

Fisk, A.T., Tittlemier, S.A., Pranschke, J.L., Norstrom, R.J., 2002. Using anthropogenic contaminants and stable isotopes to assess the feeding ecology of Greenland sharks. Ecology 83, 21622172.

Fleeger, J.W., Carman, K.R., Nisbet, R.M., 2003. Indirect effects of contaminants in aquatic ecosystems. Science of The Total Environment 317, 207-233.

Fox, J., Weisberg, S., 2010. An R companion to applied regression. Sage.

Giraldo, C., Ernande, B., Cresson, P., Kopp, D., Cachera, M., Travers-Trolet, M., Lefebvre, S., 2017. Depth gradient on the resource use of a fish community from a semi-enclosed sea. Limnol. Oceanogr. doi:10.1002/Ino.10561

Hardy, R., Keay, J.N., 1972. Seasonal variations in the chemical composition of Cornish mackerel, Scomber scombrus (L), with detailed reference to the lipids. International Journal of Food Science \& Technology 7, 125-137. doi:10.1111/j.1365-2621.1972.tb01648.x

Harmelin-Vivien, M., Cossa, D., Crochet, S., Bănaru, D., Letourneur, Y., Mellon-Duval, C., 2009. Difference of mercury bioaccumulation in red mullets from the north-western Mediterranean and Black seas. Marine Pollution Bulletin 58, 679-685.

Hislop, J.R.G., Harris, M.P., Smith, J.G.M., 1991. Variation in the calorific value and total energy content of the lesser sandeel (Ammodytes marinus) and other fish preyed on by seabirds. Journal of Zoology 224, 501-517. doi:10.1111/j.1469-7998.1991.tb06039.x

Hoffman, J.C., Sierszen, M.E., Cotter, A.M., 2015. Fish tissue lipid-C: N relationships for correcting $\delta^{13} \mathrm{C}$ values and estimating lipid content in aquatic food-web studies. Rapid Communications in Mass Spectrometry 29, 2069-2077.

Hothorn, T., Bretz, F., Westfall, P., 2008. Simultaneous inference in general parametric models. Biometrical journal 50, 346-363.

Jennings, S., van der Molen, J., 2015. Trophic levels of marine consumers from nitrogen stable isotope analysis: estimation and uncertainty. ICES Journal of Marine Science: Journal du Conseil 72, 2289-2300.

Jennings, S., Warr, K., 2003. Environmental correlates of large-scale spatial variation in the $\delta^{15} \mathrm{~N}$ of marine animals. Marine Biology 142, 1131-1140.

Käkelä, A., Furness, R.W., Kelly, A., Strandberg, U., Waldron, S., Käkelä, R., 2007. Fatty acid signatures and stable isotopes as dietary indicators in North Sea seabirds. Marine Ecology Progress Series 342, 291-301.

Kojadinovic, J., Potier, M., Le Corre, M., Cosson, R.P., Bustamante, P., 2006. Mercury content in commercial pelagic fish and its risk assessment in the Western Indian Ocean. Science of The Total Environment 366, 688-700. doi:10.1016/j.scitotenv.2006.02.006

Kopp, D., Lefebvre, S., Cachera, M., Villanueva, M.C., Ernande, B., 2015. Reorganization of a marine trophic network along an inshore-offshore gradient due to stronger pelagic-benthic coupling in coastal areas. Progress in Oceanography 130, 157-171.

Lloret, J., Planes, S., 2003. Condition, feeding and reproductive potential of white seabream Diplodus sargus as indicators of habitat quality and the effect of reserve protection in the northwestern Mediterranean. Mar Ecol Prog Ser 248, 197-208. 
Magalhães, M.C., Costa, V., Menezes, G.M., Pinho, M.R., Santos, R.S., Monteiro, L.R., 2007. Intra-and inter-specific variability in total and methylmercury bioaccumulation by eight marine fish species from the Azores. Marine pollution bulletin 54, 1654-1662.

McKinney, M.A., Dean, K., Hussey, N.E., Cliff, G., Wintner, S.P., Dudley, S.F.J., Zungu, M.P., Fisk, A.T., 2016. Global versus local causes and health implications of high mercury concentrations in sharks from the east coast of South Africa. Science of The Total Environment 541, 176-183. doi:10.1016/j.scitotenv.2015.09.074

Merayo, C., 1996. Seasonal changes in the biochemical composition of the muscle and liver of bib (Trisopterus luscus L.)(Pisces, Gadidae) from the Cantabrian Sea (N Spain). Sci. Mar 60, 489495.

Mill, A.., Pinnegar, J.K., Polunin, N.V.C., 2007. Explaining isotope trophic-step fractionation: why herbivorous fish are different. Functional Ecology 21, 1137-1145.

Murray, J., Burt, J.R., 1969. The composition of fish (Torry Advisory Note No. 38). Torry Research Station.

Nakhlé, K., Cossa, D., Claisse, D., Beliaeff, B., Simon, S., 2007. Cadmium and mercury in Seine Estuary flounders and muscle: the results of two decades of monitoring. ICES Journal of Marine Science 64, 929-938.

Panichev, N.A., Panicheva, S.E., 2015. Determination of total mercury in fish and sea products by direct thermal decomposition atomic absorption spectrometry. Food Chemistry 166, 432441. doi:10.1016/j.foodchem.2014.06.032

Payne, S.A., Johnson, B.A., Otto, R.S., 1999. Proximate composition of some north-eastern Pacific forage fish species. Fisheries Oceanography 8, 159-177. doi:10.1046/j.13652419.1999.00097.x

Pinnegar, J.K., Polunin, N.V.C., 1999. Differential fractionation of $\delta^{13} \mathrm{C}$ and $\delta^{15} \mathrm{~N}$ among fish tissues: implications for the study of trophic interactions. Functional Ecology 13, 225-231. doi:10.1046/j.1365-2435.1999.00301.x

Pohlert, T., 2015. PMCMR: Calculate Pairwise Multiple Comparisons of Mean Rank Sums. R package version 1.2. [WWW Document]. URL http://cran.r-project.org/package=PMCMR

Post, D.M., Layman, C.A., Arrington, D.A., Takimoto, G., Quattrochi, J., Montaña, C.G., 2007. Getting to the fat of the matter: models, methods and assumptions for dealing with lipids in stable isotope analysis. Oecologia 152, 179-189.

$\mathrm{R}$ Core Team, 2015. R: A language and environment for statistical computing. $R$ foundation for Statistical computing, Vienna, Austria.

Robinson, J.S., Mead, J.F., 1973. Lipid absorption and deposition in rainbow trout (Salmo gairdnerii). Canadian journal of biochemistry 51, 1050-1058.

Sardenne, F., Ménard, F., Degroote, M., Fouché, E., Guillou, G., Lebreton, B., Hollanda, S.J., Bodin, N., 2015. Methods of lipid-normalization for multi-tissue stable isotope analyses in tropical tuna. Rapid Communications in Mass Spectrometry 29, 1253-1267.

Sokal, R., Rohlf, F., 1995. Biometry (3rd edn). WH Freman and company: New York.

Tartu, S., Goutte, A., Bustamante, P., Angelier, F., Moe, B., Clément-Chastel, C., Bech, C., Gabrielsen, G.W., Bustnes, J.O., Chastel, O., 2013. To breed or not to breed: endocrine response to mercury contamination by an Arctic seabird. Biology Letters 9, 20130317.

Travers-Trolet, M., Verin, Y., 2014. CAMANOC Survey Report. doi:/10.17600/14001900

Trueman, C.N., MacKenzie, K.M., St John Glew, K., 2016. Stable isotope-based location in a shelf sea setting: accuracy and precision are comparable to light-based location methods. Methods in Ecology and Evolution.

Venables, W.N., Ripley, B.D., 2013. Modern applied statistics with S-PLUS. Springer Science \& Business Media.

Wallace, P., 1991. Seasonal variation in fat content of mackerel (Scomber scombrus L.) caught in the western English Channel, in: Fisheries Research Technical Report. Lowestoft: Directorate of Fisheries Research.

Wickham, H., 2009. ggplot2: elegant graphics for data analysis. Springer Science \& Business Media. 
Tab 1: Number of fish individuals (sample size) per species used in this study. $\mathrm{n}$ sites is the number of trawling sites where the species was sampled, total length was measured in the laboratory, trophic level is computed from nitrogen stable isotope and $\mathrm{C} / \mathrm{N}$ ratio measured in muscle tissue is a proxy of lipid content.

\begin{tabular}{|c|c|c|c|c|c|c|c|}
\hline \multirow{2}{*}{\multicolumn{2}{|c|}{ Species }} & \multirow{3}{*}{$\begin{array}{c}\text { Sample size } \\
8\end{array}$} & \multirow{3}{*}{$\begin{array}{c}\text { n sites } \\
1\end{array}$} & \multicolumn{2}{|c|}{ Total length (mm) } & \multirow{3}{*}{$\begin{array}{c}\begin{array}{c}\text { Trophic level } \\
\text { Mean } \pm \text { sd }\end{array} \\
3.25 \pm 0.10\end{array}$} & \multirow{3}{*}{$\begin{array}{l}\text { C/N ratio } \\
\text { Mean } \pm \text { sd } \\
3.28 \pm 0.04\end{array}$} \\
\hline & & & & Mean \pm sd & Min - Max & & \\
\hline Arnoglossus imperialis (Rafinesque, 1810) & Imperial scaldfish & & & $172 \pm 11$ & $159-192$ & & \\
\hline Chelidonichthys cuculus (Linnaeus, 1758) & Red gurnard & 126 & 15 & $248 \pm 47$ & $108-364$ & $3.65 \pm 0.45$ & $3.21 \pm 0.11$ \\
\hline Lepidorhombus whiffiagonis (Walbaum, 1792) & Megrim & 7 & 1 & $364 \pm 90$ & $259-478$ & $3.33 \pm 0.17$ & $3.27 \pm 0.14$ \\
\hline Melanogrammus aeglefinus (Linnaeus, 1758) & Haddock & 56 & 7 & $295 \pm 18$ & $255-335$ & $3.71 \pm 0.19$ & $3.18 \pm 0.02$ \\
\hline Merlangius merlangus (Linnaeus, 1758) & Whiting & 73 & 8 & $279 \pm 42$ & $143-350$ & $4.22 \pm 0.22$ & $3.13 \pm 0.04$ \\
\hline Merluccius merluccius Linnaeus, 1758 & European hake & 6 & 3 & $329 \pm 53$ & $257-385$ & $3.53 \pm 0.29$ & $3.14 \pm 0.01$ \\
\hline Microstomus kitt (Walbaum, 1792) & Lemon sole & 11 & 3 & $225 \pm 19$ & $200-254$ & $3.16 \pm 0.12$ & $3.22 \pm 0.05$ \\
\hline Microchirus variegatus (Donovan, 1808) & Thickback sole & 23 & 6 & $155 \pm 21$ & $106-185$ & $3.57 \pm 0.14$ & $3.20 \pm 0.03$ \\
\hline Pleuronectes platessa Linnaeus, 1758 & European plaice & 28 & 7 & $330 \pm 49$ & $225-426$ & $3.91 \pm 0.63$ & $3.19 \pm 0.03$ \\
\hline Scomber scombrus Linnaeus, 1758 & Atlantic mackerel & 151 & 17 & $297 \pm 51$ & $169-410$ & $3.59 \pm 0.53$ & $6.35 \pm 1.64$ \\
\hline Spondyliosoma cantharus (Linnaeus, 1758) & Black seabream & 59 & 8 & $174 \pm 68$ & $65-297$ & $3.91 \pm 0.19$ & $3.71 \pm 0.41$ \\
\hline Trachurus trachurus (Linnaeus, 1758) & Atlantic horse mackerel & 145 & 16 & $227 \pm 50$ & $120-315$ & $3.82 \pm 0.35$ & $3.92 \pm 0.61$ \\
\hline Trisopterus luscus (Linnaeus, 1758) & Pouting & 49 & 9 & $231 \pm 61$ & $129-329$ & $4.12 \pm 0.23$ & $3.15 \pm 0.03$ \\
\hline Trisopterus minutus (Linnaeus, 1758) & Poor cod & 75 & 11 & $145 \pm 22$ & $86-175$ & $3.69 \pm 0.20$ & $3.18 \pm 0.04$ \\
\hline Zeus faber Linnaeus, 1758 & John Dory & 31 & 6 & $299 \pm 139$ & $107-522$ & $3.99 \pm 0.33$ & $3.17 \pm 0.06$ \\
\hline
\end{tabular}


Tab. 2: Results of the Student test comparing actual mean conversion value to the theoretical ratio of 5. Significant differences are highlighted with bold characters

\begin{tabular}{|c|c|c|c|c|c|c|}
\hline \multirow{2}{*}{ Species } & \multirow{2}{*}{$\begin{array}{l}\text { Measured conversion factor } \\
\text { Mean } \pm \text { sd }\end{array}$} & \multirow{2}{*}{$\mathbf{t}$} & \multirow{2}{*}{ df } & \multirow{2}{*}{$p$-value } & \multicolumn{2}{|c|}{$95 \%$ confidence interval } \\
\hline & & & & & $\min$ & $\max$ \\
\hline Scomber scombrus & $3.62 \pm 0.33$ & -51.39 & 150 & $<10^{-4}$ & 3.57 & 3.68 \\
\hline Trachurus trachurus & $4.16 \pm 0.34$ & -29.22 & 144 & $<10^{-4}$ & 4.13 & 4.24 \\
\hline Spondyliosoma cantharus & $4.30 \pm 0.36$ & -15.02 & 58 & $<10^{-4}$ & 4.20 & 4.39 \\
\hline Chelidonichthys cuculus & $4.37 \pm 0.35$ & -20.22 & 126 & $<10^{-4}$ & 4.31 & 4.43 \\
\hline Microstomus kitt & $4.38 \pm 0.07$ & -29.16 & 10 & $<10^{-4}$ & 4.33 & 4.42 \\
\hline Lepidorhombus whiffiagonis & $4.46 \pm 0.14$ & -9.97 & 6 & $<10^{-4}$ & 4.33 & 4.59 \\
\hline Arnoglossus imperialis & $4.48 \pm 0.38$ & -3.89 & 7 & 0.006 & 4.16 & 4.80 \\
\hline Zeus faber & $4.70 \pm 0.21$ & -7.96 & 30 & $<10^{-4}$ & 4.62 & 4.78 \\
\hline Trisopterus minutus & $4.76 \pm 0.36$ & -5.72 & 74 & $<10^{-4}$ & 4.68 & 4.85 \\
\hline Pleuronectes platessa & $4.79 \pm 0.25$ & -4.57 & 27 & $<10^{-4}$ & 4.69 & 4.88 \\
\hline Microchirus variegatus & $4.82 \pm 0.54$ & -1.55 & 22 & 0.135 & 4.59 & 5.06 \\
\hline Melanogrammus aeglefinus & $4.96 \pm 0.23$ & -1.36 & 55 & 0.180 & 4.90 & 5.02 \\
\hline Trisopterus luscus & $4.99 \pm 0.25$ & -0.15 & 48 & 0.885 & 4.92 & 5.07 \\
\hline Merluccius merluccius & $5.25 \pm 1.37$ & -0.71 & 5 & 0.509 & 4.25 & 5.53 \\
\hline Merlangius merlangus & $5.51 \pm 0.44$ & 9.85 & 72 & $<10^{-4}$ & 5.41 & 5.61 \\
\hline
\end{tabular}


Tab. 3: Parameters of the Spearman correlation between wet:dry ratio and biological descriptor. Significance of the correlation is denoted by symbols after $\rho$ value $\left(* * * p\right.$-value $<0.001,{ }^{* *} p$-value $<0.01, * p$-value $<0.05 \mathrm{NS}$ : non-significant, pvalue $\left.>0.05\right)$. Plots of the relationships are provided in supplementary material.

\begin{tabular}{|c|c|c|c|}
\hline & Total length & $\mathrm{C}: \mathrm{N}$ & Trophic level \\
\hline Scomber scombrus & $-0.50^{* * *}$ & $-0.77^{* * *}$ & $-0.35^{* * *}$ \\
\hline Trachurus trachurus & $-0.08^{\mathrm{NS}}$ & $-0.47^{* * *}$ & $-0.21^{* *}$ \\
\hline Spondyliosoma cantharus & $-0.29^{* * *}$ & $-0.48^{* * *}$ & $0.23^{\mathrm{NS}}$ \\
\hline Chelidonichthys cuculus & $-0.13^{\mathrm{NS}}$ & $-0.45^{* * *}$ & $-0.35 * * *$ \\
\hline Microstomus kitt & $0.38^{\mathrm{NS}}$ & $-0.42^{\mathrm{NS}}$ & $-0.16^{\mathrm{NS}}$ \\
\hline Lepidorhombus whiffiagonis & $-0.14^{\mathrm{NS}}$ & $-0.05^{\text {NS }}$ & $-0.29^{\mathrm{NS}}$ \\
\hline Arnoglossus imperialis & $-0.19^{\mathrm{NS}}$ & $-0.64^{\mathrm{NS}}$ & $-0.36^{\mathrm{NS}}$ \\
\hline Zeus faber & $-0.52^{* * *}$ & $0.11^{\mathrm{NS}}$ & $-0.29^{\mathrm{NS}}$ \\
\hline Trisopterus minutus & $-0.28^{* *}$ & $-0.35^{* * *}$ & $0.11^{\mathrm{NS}}$ \\
\hline Pleuronectes platessa & $-0.11^{\mathrm{NS}}$ & $-0.09^{\mathrm{NS}}$ & $-0.17^{\mathrm{NS}}$ \\
\hline Microchirus variegatus & $-0.11^{\mathrm{NS}}$ & $-0.15^{\mathrm{NS}}$ & $0.11^{\mathrm{NS}}$ \\
\hline Melanogrammus aeglefinus & $-0.06^{\mathrm{NS}}$ & $0.03^{\mathrm{NS}}$ & $-0.28^{*}$ \\
\hline Trisopterus luscus & $0.13^{\mathrm{NS}}$ & $-0.30^{*}$ & $-0.08^{\mathrm{NS}}$ \\
\hline Merluccius merluccius & $-0.66^{\mathrm{NS}}$ & $-0.19^{\mathrm{NS}}$ & $-0.60^{\mathrm{NS}}$ \\
\hline Merlangius merlangus & $0.25^{* *}$ & $-0.02^{\mathrm{NS}}$ & $0.28^{* *}$ \\
\hline
\end{tabular}


Fig. 1: Interspecific variation in wet:dry mass in caudal muscle. Species are sorted by increasing average ratio value. Box hinges are the $1^{\text {st }}$ and $3^{\text {rd }}$ quartiles; line is the median value, gray dot the mean value. Whiskers extend from the hinge to the highest or lowest value that is within $1.5 \times$ interquartile range, Horizontal hatched line represent the 5 theoretical ratio commonly used. Species with different letters exhibit significantly different ratios.

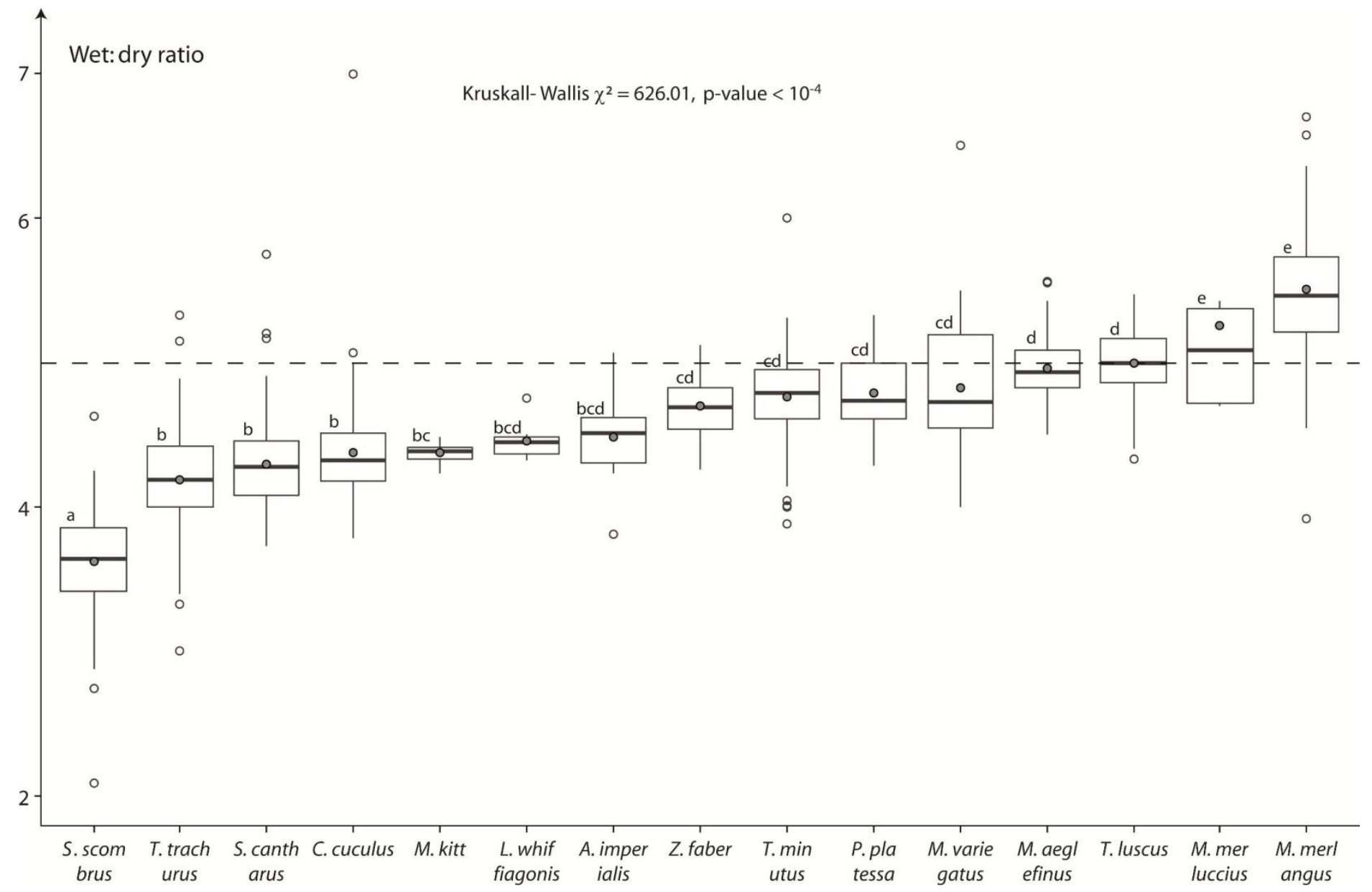


Fig. 2: Correlation between $\mathrm{C} / \mathrm{N}$ ratio ( $\mathrm{x}$ axis) considered as a proxy of lipid content, and wet:dry ratio in muscle. Solid line is the linear regression calculated for each species separately, dashed line the average regression line calculated for all species together. Parameters of the regression ( $r$ and pvalues) are provided in Table 2

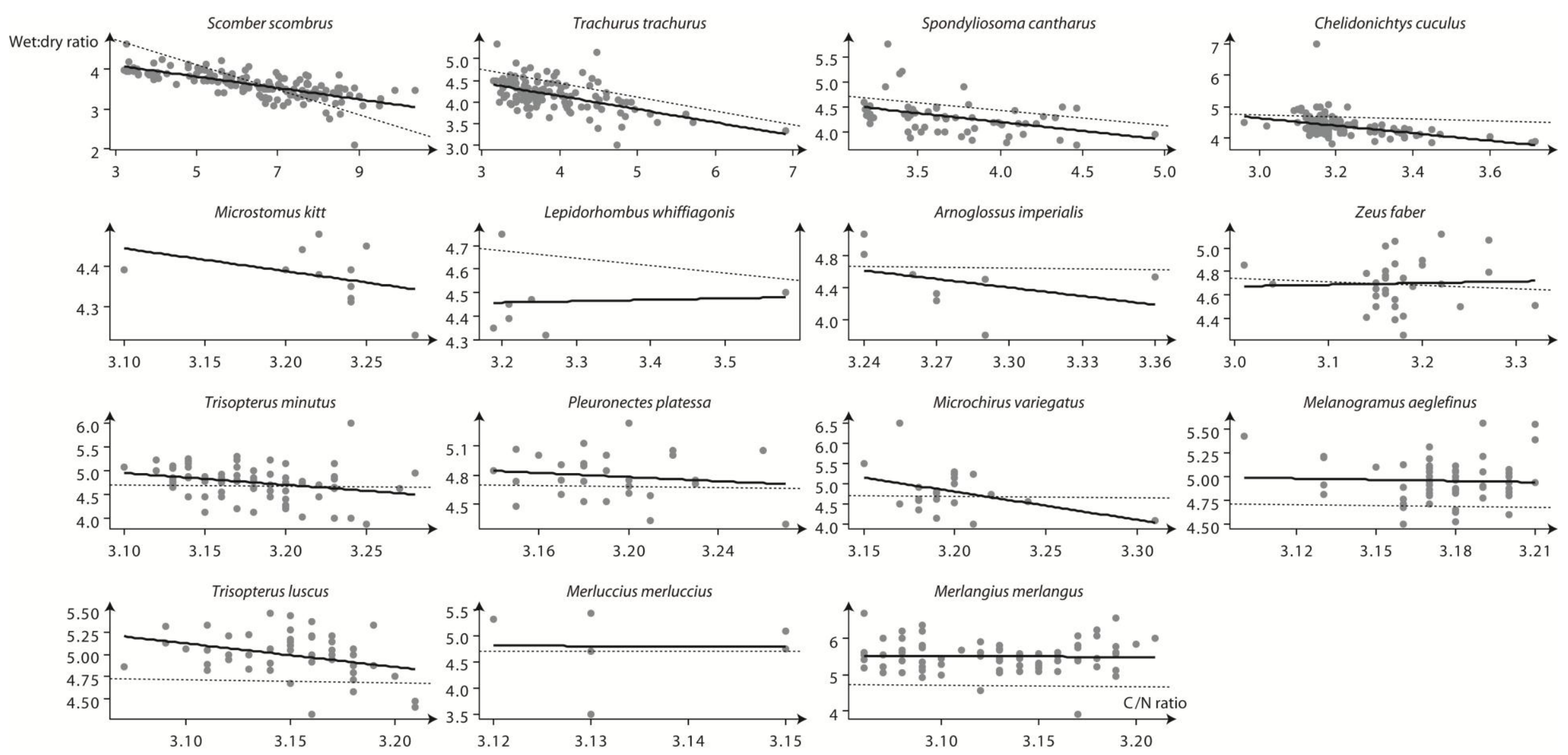


Fig. 3: Intra specific variation in wet:dry ratio between caudal and dorsal muscle. The solid line is the regression line, the dotted line is the $y=x$ line.

Parameters of the correlation are displayed in the upper left part of each panel, parameters of the Wilcoxon comparison test in the lower right part.
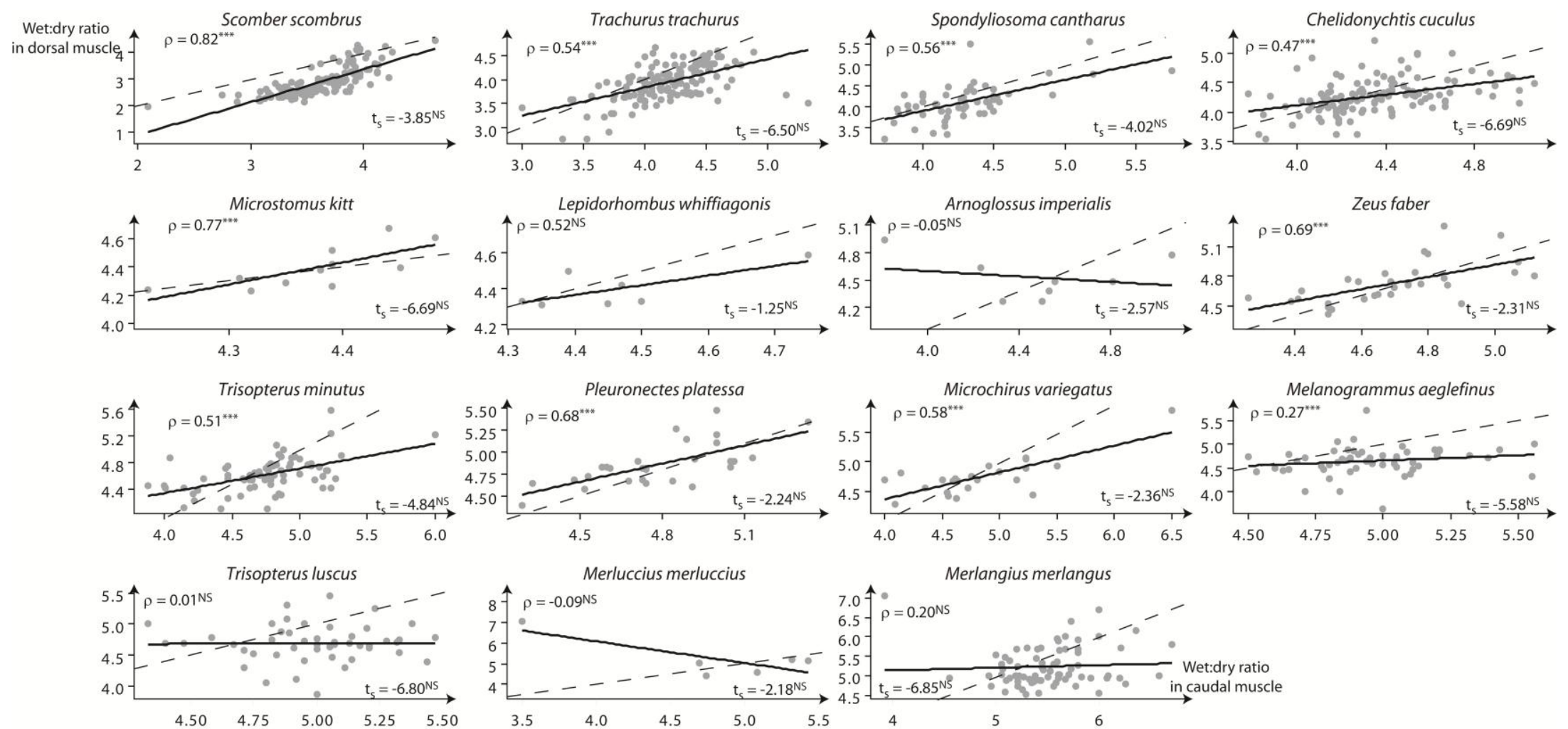
Fig. 4: Percentage of error associated with the use of the theoretical conversion factor of 5 rather than the measured conversion factor, when converting concentration measured relatively to dry mass to a concentration measured relatively to wet mass. Species considered for discussion in the text are highlighted with their full name. Error bars are calculated considering minimal and maximal values for the $95 \%$ credibility interval (Tab. 2) for all species but L. forbesii (displayed with a square to differentiate it from fish species), S. solea and L. piscatorius that are displayed for informative purposes only. Colors represent the three groups of species, depending on their average measured conversion factor: white: $\mathrm{CF}<5$, grey $\mathrm{CF}=5$, black $\mathrm{CF}>5$.

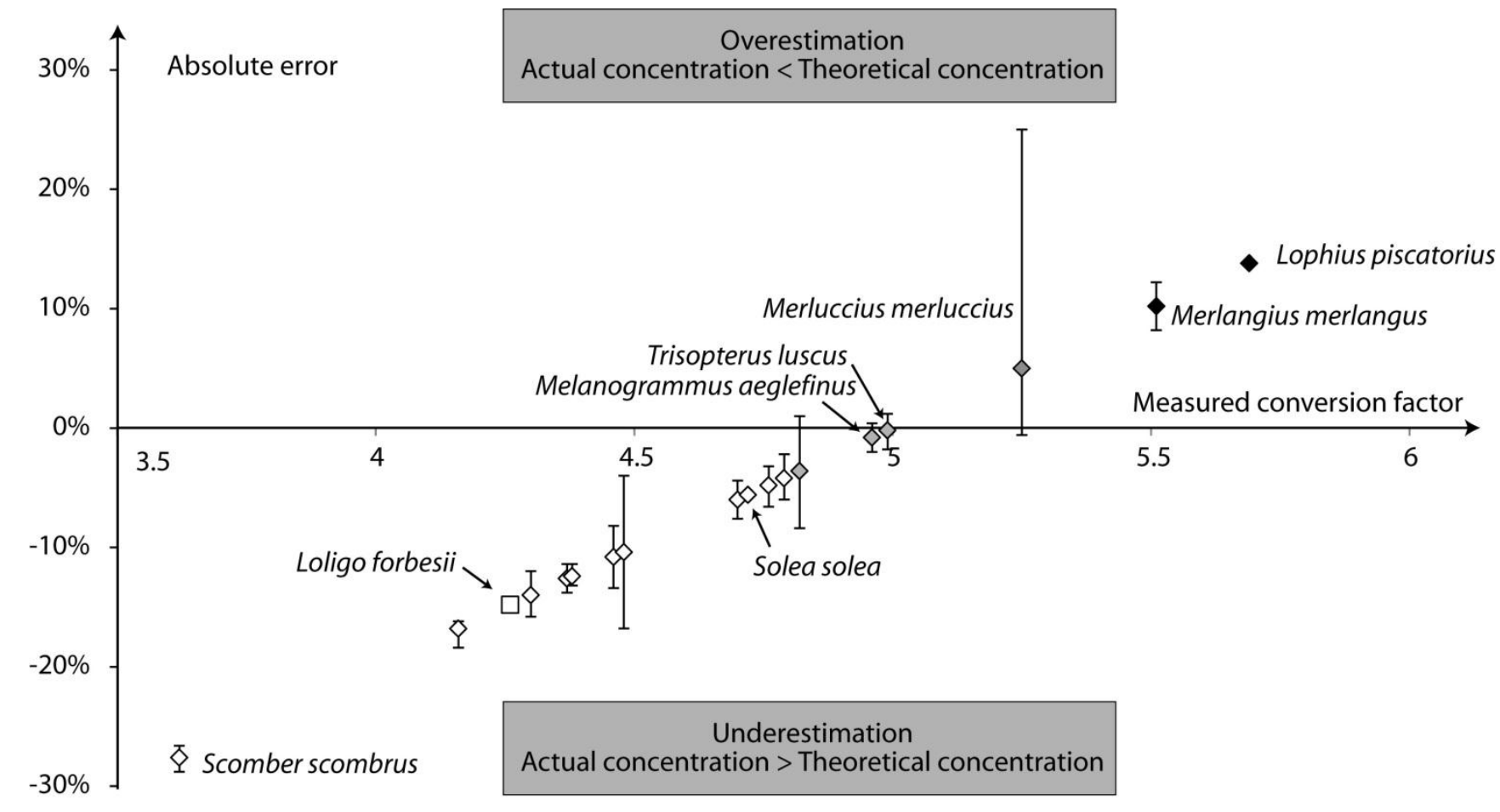


1 Electronic supplementary material

2 Fig. S1: Map of sampling points

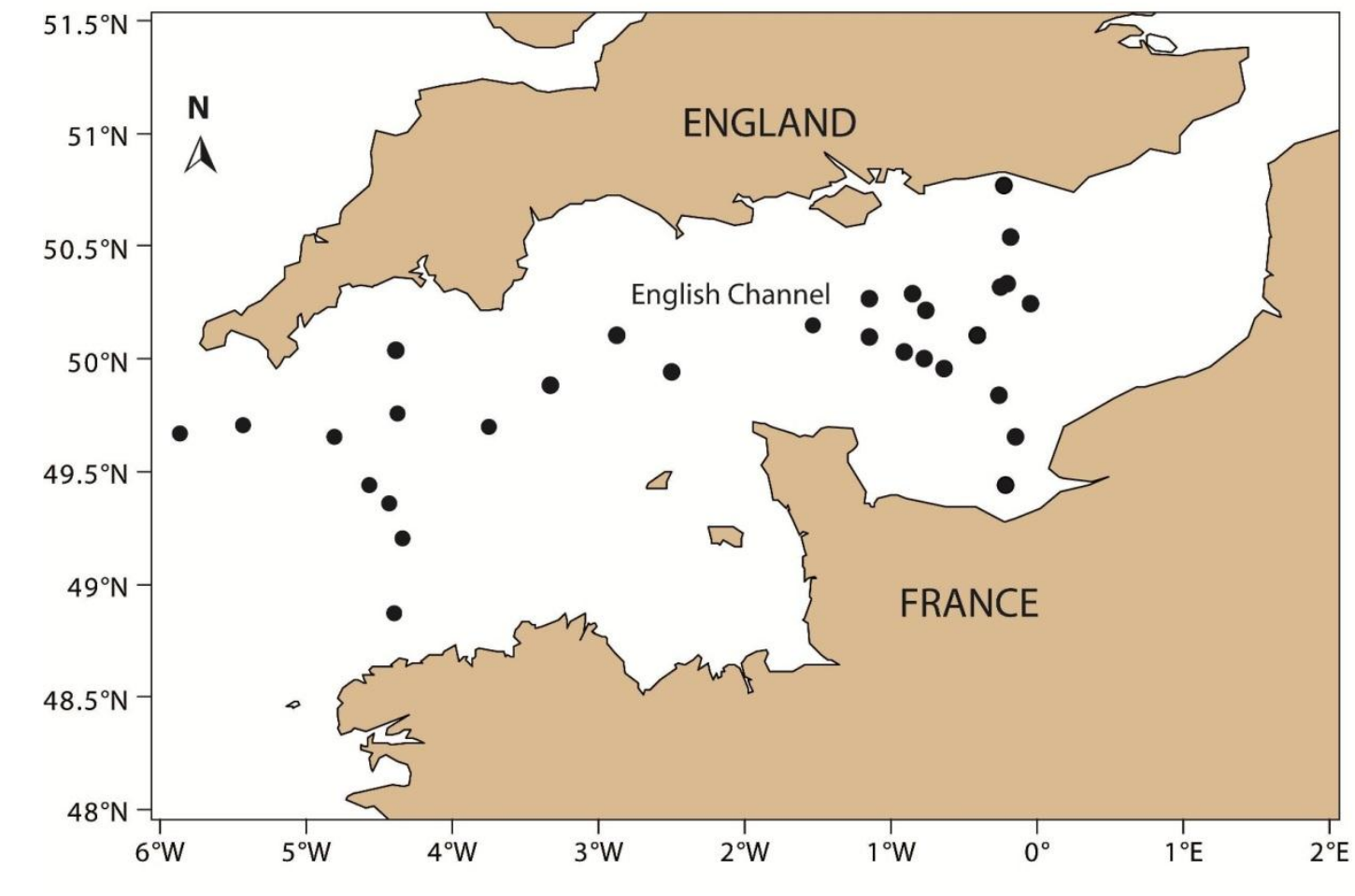


Fig. S2: Correlation between total length (in $\mathrm{mm}, \mathrm{x}$ axis) and wet:dry ratio in muscle. Full line is the linear regression calculated for each species separately,

5 dashed line the average regression line calculated for all species together. Correlation parameters ( $\rho$ and pvalues) are provided in Table 2
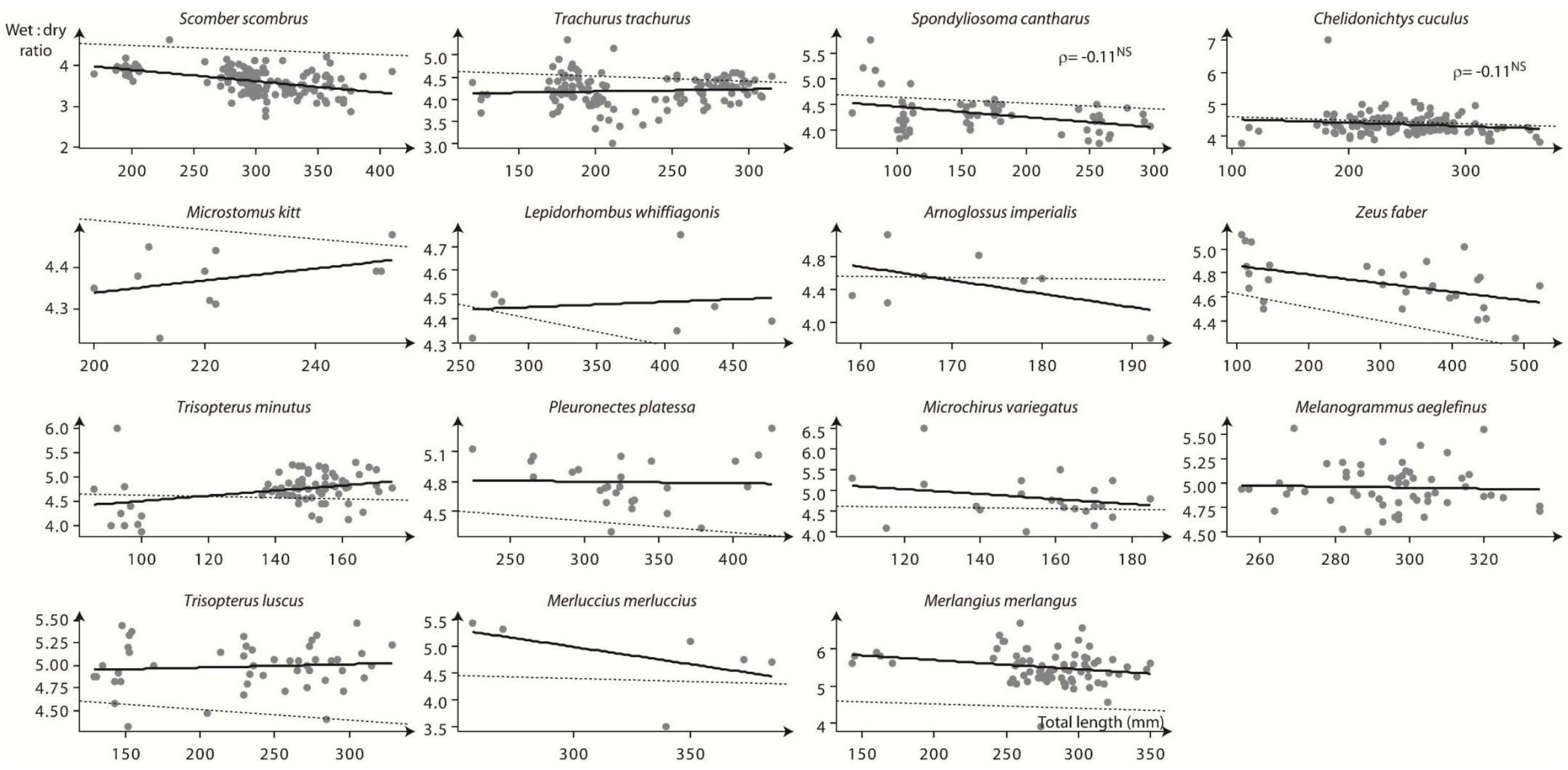

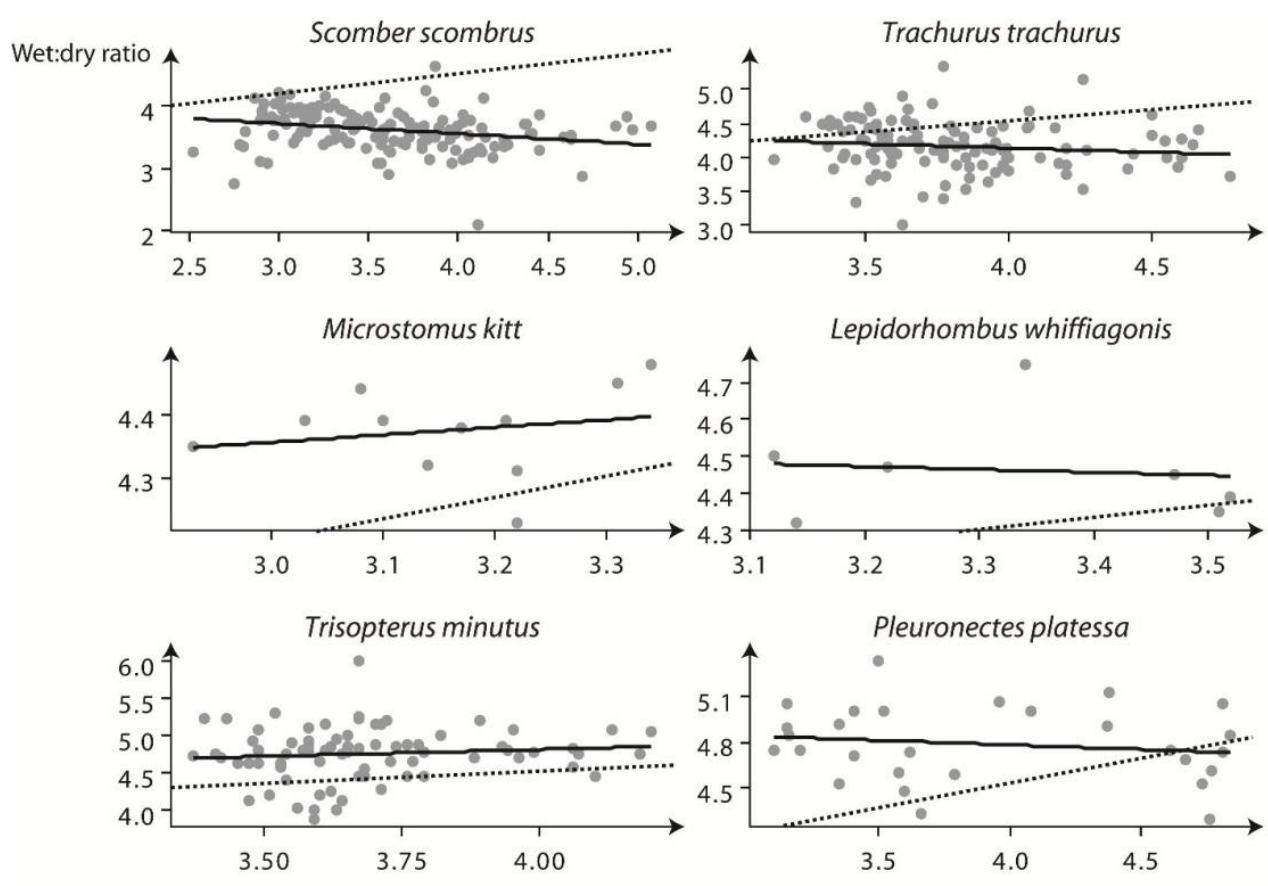

Trisopterus luscus
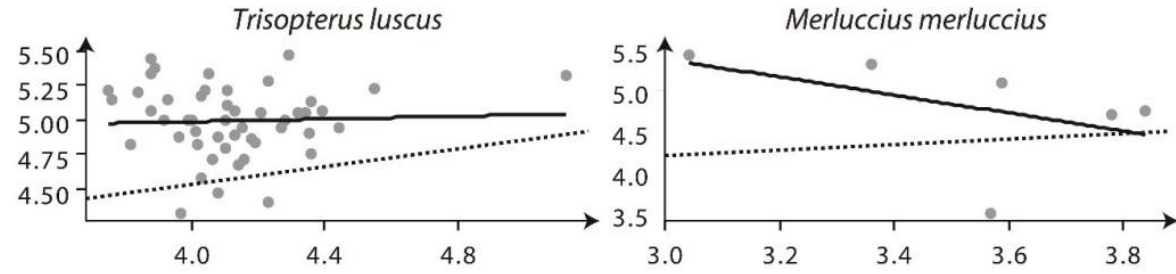

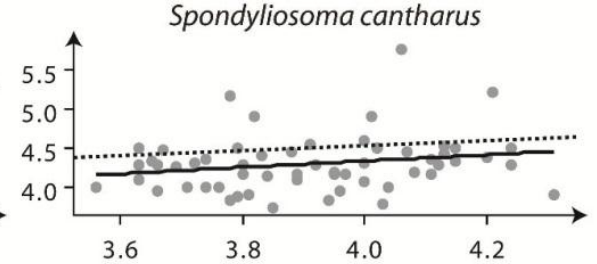

Arnoglossus imperialis
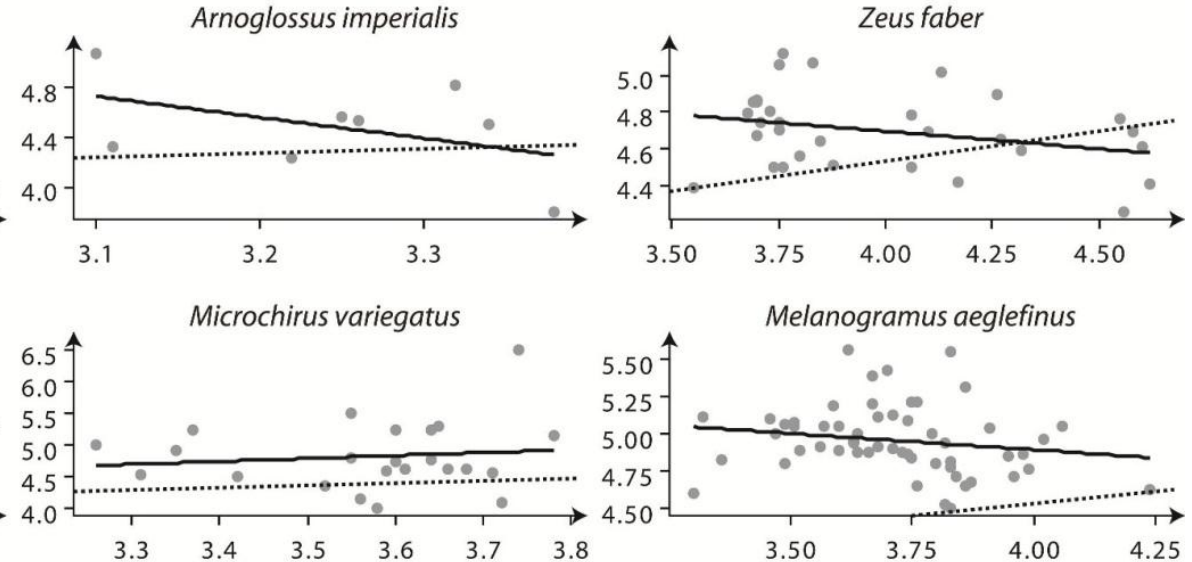

Merlangius merlangus

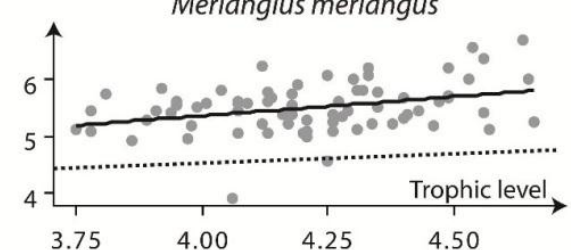


Tab. S1: Sampling details, biometric parameters and conversion factors for Loligo forbesii, Lophius piscatorius and Solea solea. These species were not included in the statistical analyses due to their low sample size.

\begin{tabular}{lccccc}
\hline \multicolumn{1}{c}{ Species } & & Sample size & \multicolumn{2}{c}{ Total length (mm) } & Measured conversion factor \\
& & & Mean \pm sd & Min - Max & Mean \pm sd \\
\hline Loligo forbesii Steenstrup, 1857 & Veined squid & 17 & $222 \pm 45$ & $145-341$ & $4.26 \pm 0.24$ \\
Lophius piscatorius Linnaeus, 1758 & Angler & 4 & $429 \pm 107$ & $323-548$ & $5.69 \pm 0.32$ \\
Solea solea (Linnaeus, 1758) & Common sole & 4 & $313 \pm 17$ & $288-325$ & $4.72 \pm 0.23$ \\
\hline
\end{tabular}


Tab. S2: Results of ANCOVAs comparing effects of species or biological factors on dry:wet ratio. Post-hoc tests results only present significant differences.

\begin{tabular}{|c|c|c|c|c|}
\hline & DF & $\mathrm{F}$ & $p$-value & Tukey's posthoc test results \\
\hline C:N (Box-Cox transformation) & 1 & 611.73 & $<0.00001$ & \\
\hline Species & 14 & 60.88 & $<0.0001$ & $\begin{array}{l}\text { C. cuculus } \neq(S . \text { scombrus, } T \text {. trachurus) } \\
\text { T. trachurus } \neq \text { S. scombrus }\end{array}$ \\
\hline $\mathrm{C} / \mathrm{N} \times$ Species & 14 & 6.41 & $<0.0001$ & C. cuculus $\neq$ (S. scombrus, T. trachurus) \\
\hline Trophic level (untransformed) & 1 & 13.98 & $<0.0001$ & \\
\hline Species & 14 & 141.69 & $<0.0001$ & C. cuculus $\neq$ (M. merlangus, S. scombrus) \\
\hline Trophic level $\times$ species & 14 & 2.81 & $<0.0001$ & M. merlangus $\neq$ (C. cuculus, $P$. platessa, S. scombrus, T. trachurus, Z. faber) \\
\hline Total length (untransformed) & 1 & 22.64 & $<0.0001$ & \\
\hline Species & 14 & 151.34 & $<0.0001$ & $\begin{array}{l}\text { M. merlangus } \neq \text { (C. cuculus, S. scombrus, S. cantharus, T. trachurus, T. luscus, T. minutus, Z. faber) } \\
\text { T. trachurus } \neq(T \text {. luscus, Z. faber) }\end{array}$ \\
\hline LT $\times$ species & 14 & 3.46 & $<0.0001$ & $\begin{array}{l}\text { T. minutus } \neq \text { (C. cuculus, M. merluccius, M. merlangus, S. scombrus, S. cantharus, Z. faber) } \\
\text { S. scombrus } \neq(T \text {. trachurus, } T \text {. luscus) }\end{array}$ \\
\hline
\end{tabular}

